\title{
The Atomic Arrangement of Cr-rich Tourmaline from the \#1 Mine, Balmat, St. Lawrence County, New York, USA
}

\author{
Steven G. Dannenberg ${ }^{1}$, Devany Di Paolo ${ }^{1}$, Alix M. Ehlers ${ }^{1}$, Kyle P. McCarthy ${ }^{1}$, \\ Mark T. Mancini ${ }^{1}$, Matthew B. Reuter ${ }^{1}$, Dennis M. Seth Jr. ${ }^{1}$, Zihui Song ${ }^{1}$, Maria I. Valladares ${ }^{1}$, \\ Xuanfu Zhu ${ }^{1}$, John M. Hughes ${ }^{1, *}$ and Marian V. Lupulescu ${ }^{2}$ \\ 1 Department of Geology, University of Vermont, Burlington, VT 05405, USA \\ 2 New York State Museum, Research and Collections, 3140 CEC, Albany, NY 12230, USA \\ * Correspondence: jmhughes@uvm.edu; Tel: +1-802-656-9443
}

Received: 16 May 2019; Accepted: 27 June 2019; Published: 28 June 2019

\begin{abstract}
Chromium-bearing tourmalines are rare. Chromium-rich tourmaline from the northwestern part of the Adirondack Mountains in the Adirondack Lowlands is among the most chromium-rich tourmalines found to date. The mineral, with $>21.0 \mathrm{wt}$. $\% \mathrm{Cr}_{2} \mathrm{O}_{3}$, is from the marble-hosted talc-tremolite-cummingtonite schist in the \#1 mine in Balmat, St. Lawrence County, New York. The atomic arrangement of the sample $(a=16.0242(3) \AA, c=7.3002(2) \AA)$ was refined to $R 1=0.0139$. The composition, from chemical analyses and optimization of the formula, is ${ }^{X}\left(\mathrm{Ca}_{0.22} \mathrm{Na}_{0.69} \mathrm{~K}_{0.01}\right)$ ${ }^{Y}\left(\mathrm{Cr}^{3+}{ }_{1.68} \mathrm{Mg}_{0.80} \mathrm{Ti}_{0.13} \mathrm{~V}_{0.06} \mathrm{Mn}_{0.02} \mathrm{Fe}_{0.02} \mathrm{Li}_{0.29}\right)^{\mathrm{Z}}\left(\mathrm{Al}_{3.11} \mathrm{Cr}^{3+}{ }_{1.18} \mathrm{Mg}_{1.70} \mathrm{Fe}_{0.01}\right)^{T}\left(\mathrm{Si}_{5.93} \mathrm{Al}_{0.07}\right) \mathrm{B}_{3} \mathrm{O}_{27} \mathrm{OH}_{3.99}$ $\mathrm{F}_{0.01}$. There has been extensive debate over the ordering of $\mathrm{Cr}^{3+}$ between the tourmaline $\mathrm{Y}$ and $\mathrm{Z}$ octahedral sites. Recent work has suggested that, at low concentrations $(<\sim 1.03$ apfu), the substituent $\mathrm{Cr}^{3+}$ is ordered into the $Y$-site, whereas, at greater concentrations, the substituent is disordered over both octahedral sites. An analysis of nine recently published, high-precision structures of chromium-bearing tourmaline, in combination with the Adirondack tourmaline, suggests that structural changes to the $Y$-site at low concentrations of $\mathrm{Cr}^{3+}$ induce changes in the Z-site that make it more amenable to incorporation of the $\mathrm{Cr}^{3+}$ substituents by increasing $\langle\mathrm{Z}-\mathrm{O}\rangle$. The bond lengths change to lower the bond-valence sum of $\mathrm{Cr}^{3+}$ in the Z-site of the chromium-dravite, making that site more amenable to the substituent. Calculations suggest that the $Z$-site begins to accept substituent $\mathrm{Cr}^{3+}$ when the bond valence sum of that ion in $Z$ reduces to a value of $\sim 3.36$ valence units.
\end{abstract}

Keywords: tourmaline; chromium-dravite; Balmat mine; St. Lawrence County; New York

\section{Introduction and Geologic Setting}

Tourmaline is among the last major silicate minerals to have the details of its atomic arrangement elucidated, and the last 20 years have seen a major effort in unraveling the crystal chemistry of the phase. Because of the variety of cation sites $((X-\mathrm{O} 9)$ polyhedron, $(Y-\mathrm{O} 6)$ and $(\mathrm{Z}-\mathrm{O} 6)$ octahedra, and $(T-\mathrm{O} 4)$ tetrahedron), tourmaline incorporates a wide variety of substituent elements, and chromium is among them. Cr-bearing tourmaline is relatively rare, but samples with up to $\sim 36 \mathrm{wt}$. $\% \mathrm{Cr}_{2} \mathrm{O}_{3}$ have been found. A recent paper [1] detailed the major localities and provided new insight into the atomic ordering of substituent $\mathrm{Cr}$, and substituent $\mathrm{Cr}$ in tourmaline has been the subject of recent studies [2,3].

In this work, we examined a purported chromium-dravite crystal from marble-hosted talc-tremolite-cummingtonite schist in the \#1 mine in Balmat, St. Lawrence County, New York. The mineral was previously described [4], sans crystal structure, and the authors provided the geological context and chemical analysis for the phase. Here, we report the atomic arrangement of 
Al-rich chromium-dravite described in that work. The reported high-precision structure refinement allows additional elucidation of cation ordering in the phase.

A note is in order on the mineral nomenclature used in this work. In the original work on this tourmaline [4], the authors labeled the phase an Al-rich chromium-dravite. This name was applied without the benefit of a structure analysis and before the more recent proffering of a revised tourmaline nomenclature [5]. The structure described herein is shown to have significant $\mathrm{Cr}$ in both the $Y$ and $Z$ crystallographic sites, with $\mathrm{Cr}$ dominant in the $Y$-site. Indeed, in the description of type oxy-chromium-dravite [6], investigators demonstrated that $\mathrm{Cr}^{3+}$ was dominant in both the $Y$ and $Z$ tourmaline sites. It is of interest that previous authors [1] suggested that the definition of chromium-dravite requires revision to reflect the dominance of $\mathrm{Cr}$ in both the $Y$ and $Z$ sites, as noted in type oxy-chromium-dravite [6].

The geologic setting of the New York State chromium-bearing tourmaline has been described in detail [4]. The following brief section is based on that work, and the reader is referred to that paper for further details of the geology. The sample was obtained from the northwestern part of the Adirondack Mountains in the Adirondack Lowlands. The Lowlands are comprised of two distinct formations, the Upper and Lower Marble Formations, both units having a NW-SW trend. The Upper Marble Formation is characterized by the sequences of shallow water carbonates, evaporites and talc-tremolite-cummingtonite schist. In general, tourmaline is found in the alternating layers of calcitic marbles and talc-tremolite-cummingtonite schists [7-9]. The sample analyzed in this paper occurs in a tremolite pod within this formation at the \#1 Mine located in Balmat, St. Lawrence County, New York. The chromium-dravite crosscuts the pre-existing foliation, which appears as light- to dark-green in tremolite-quartz rock while also appearing in dark-green patches. The chromium-dravite crystals associated with tremolite are 0.1 to $0.5 \mathrm{~mm}$ in dimension, whereas chromium-dravite crystals less than $0.1 \mathrm{~mm}$ are typically found as quartz or phlogopite inclusions. The Lower Marble Formation is comprised of dolomitic marbles, calc-silicates, quartzites, gneisses, and tourmalines [10].

\section{Methods}

The X-ray diffraction data on the New York chromium-dravite were collected with a Bruker Apex II CCD single-crystal diffractometer (Bruker, Madison, WI, USA) using graphite-monochromated Mo $K \alpha$ radiation. The data were collected for a redundant sphere of reciprocal space (average redundancy $\approx 9.75$ ) and were integrated and corrected for Lorentz and polarization factors and absorption using the Bruker Apex2 package of programs. The atomic arrangement was refined in space group $R 3 m$ on $F^{2}$, with SHELXL-97 [11] using neutral-atom scattering factors and full-matrix least-squares, minimizing the function $\Sigma w\left(F_{\mathrm{o}}{ }^{2}-{F_{\mathrm{c}}}^{2}\right)^{2}$ with no restraints. All non-hydrogen atoms were refined with anisotropic temperature factors, an extinction coefficient was also refined. The hydrogen atom associated with the $\mathrm{O} 3$ site was easily located by difference maps and refined without constraint. The $\mathrm{H}$ atom associated with $\mathrm{O}(\mathrm{H}) 1$ was also located, but site refinement demonstrated that there were $0.32(12) \mathrm{H}$ atoms in that site, and the veracity of the refinement of $1 / 3$ of a $H$ atom is not considered viable, and thus not included in the refinement. Occupancy of the $X$-site was modeled with Na scattering factors, as that is the dominant occupant of the $X$ site. Because of the substantial ${ }^{X} \mathrm{Ca}$, as well, the occupancy of that site, when modeled with Na scattering factors, is $>1.0$, as expected.

The New York chromium-dravite had originally been described, without structural data, as having all $\mathrm{Cr}$ ordered into the Z-site alone. Initial refinements, however, demonstrated that the occupants of the tourmaline $Y$ site had greater scattering power than $\mathrm{Mg}$ alone and the occupants of the tourmaline $\mathrm{Z}$ site had greater scattering power than $\mathrm{Al}$ alone. Because of the dominant octahedral occupants of $\mathrm{Mg}-\mathrm{Al}-\mathrm{Cr}$ in the sample, it was evident that $\mathrm{Cr}$ was a substituent in both the $\mathrm{Y}$ and $\mathrm{Z}$ octahedral sites. Final refinement was thus undertaken with $\mathrm{Mg}$ and $\mathrm{Cr}$ occupying the $Y$ site, with the constraint $(\mathrm{Mg}+\mathrm{Cr})=1$, and $\mathrm{Al}$ and $\mathrm{Cr}$ occupying the $\mathrm{Z}$ site, with the constraint $(\mathrm{Al}+\mathrm{Cr})=1$.

The details of crystal data, data collection, and structure refinement are summarized in Table 1, and atomic positions and equivalent isotropic displacement parameters are given in 
Table 2, bond lengths are shown in Table 3. A list of observed and calculated structure factors and Crystallographic Information File (CIF) (in Supplementary Materials) for the structure may be obtained as noted subsequently.

Subsequent to the structure analysis, the studied crystal was submitted for electron microprobe analysis. Data were obtained using a Cameca SX 100 at Rensselaer Polytechnic Institute, Troy, NY, USA. The crystal was mounted in epoxy and polished. Six spots were analyzed on that crystal, using accelerating voltage of $15 \mathrm{Kev}$, beam current $20 \mathrm{nA}$ and beam diameter 4 microns. The results of the chemical analysis (average of six analyses), range of analyses, and standards used in the analysis are given in Table 4.

Table 1. Sample and crystal data for NY chromium-dravite.

\begin{tabular}{cc}
\hline Space group & $R 3 m$ \\
Unit cell dimensions & $a=16.0242(3) \AA$ \\
Volume & $c=7.3002(2) \AA$ \\
F(000) & $1623.37(8) \AA^{3}$ \\
Theta range & 1545 \\
Index ranges & $2.54^{\circ}$ to $33.00^{\circ}$ \\
Reflections & 11,837 \\
Independent reflections & $1438\left[R_{\text {int }}=0.0215\right]$ \\
Refinement method & Full-matrix least-squares on $F^{2}$ \\
Refinement program & SHELXL-2014/7 $($ Sheldrick, 2015$)$ \\
Function minimized & $1438 / 0 / 94$ \\
Data/restraints/parameters & 1.080 \\
Goodness-of-fit on $F^{2}$ & 1422 data; $I>2 \sigma(\mathrm{I})$ \\
Final $R$ indices & all data \\
& $w=1 /\left[\sigma^{2}\left(F_{\mathrm{o}}{ }^{2}\right)+(0.0191 P)^{2}+0.5287 P\right]$ \\
Weighting scheme & where $P=\left(F_{\mathrm{o}}{ }^{2}+2 F_{\mathrm{c}}{ }^{2}\right) / 3$ \\
Extinction coefficient & $0.0000(1)$ \\
Largest diff. peaks & 0.369 and $-0.313 \mathrm{e} \AA^{-3}$ \\
\hline
\end{tabular}

Table 2. Atomic coordinates and equivalent isotropic atomic displacement parameters $\left(\AA^{2}\right)$ for N.Y. chromium-dravite. $U(e q)$ is defined as one-third of the trace of the orthogonalized $\mathrm{U}_{\mathrm{ij}}$ tensor.

\begin{tabular}{cccccc}
\hline Atom & $x / a$ & $y / b$ & $z / c$ & $\boldsymbol{U}(\boldsymbol{e q})$ & Occ. \\
\hline $\mathrm{NaX}$ & 0 & 0 & $3 / 4$ & $0.0112(4)$ & $\mathrm{Na}_{1.27(3)}$ \\
$\mathrm{Si}$ & $0.80930(3)$ & $0.81101(3)$ & $0.9755(2)$ & $0.00579(11)$ & $\mathrm{Si}_{1.00}$ \\
$\mathrm{~B}$ & $0.89016(10)$ & $0.78032(19)$ & $0.5218(4)$ & $0.0075(4)$ & $\mathrm{B}_{1.00}$ \\
$\mathrm{Cr} Y$ & $0.87614(3)$ & $0.93807(2)$ & $0.3381(2)$ & $0.00587(15)$ & $\mathrm{Cr}_{0.588(6)} \mathrm{Mg}_{0.412}$ \\
$\mathrm{AlZ}$ & $0.70206(3)$ & $0.73811(3)$ & $0.3651(2)$ & $0.00620(11)$ & $\mathrm{Al}_{0.782(3)} \mathrm{Cr}_{0.218}$ \\
O1 & 0 & 0 & $0.2074(4)$ & $0.0081(5)$ & $\mathrm{O}_{1.00}$ \\
$\mathrm{O} 2$ & $0.93967(6)$ & $0.87933(13)$ & $0.4896(3)$ & $0.0094(3)$ & $\mathrm{O}_{1.00}$ \\
$\mathrm{O} 3$ & $0.74056(14)$ & $0.87028(7)$ & $0.4644(3)$ & $0.0118(3)$ & $\mathrm{O}_{1.00}$ \\
$\mathrm{H} 3$ & $0.749(4)$ & $0.8744(18)$ & $1.577(7)$ & $0.054(16)$ & $\mathrm{H}_{1.00}$ \\
$\mathrm{O} 4$ & $0.90761(7)$ & $0.81522(14)$ & $0.9037(3)$ & $0.0113(3)$ & $\mathrm{O}_{1.00}$ \\
O5 & $0.81814(14)$ & $0.90907(7)$ & $0.8839(3)$ & $0.0108(3)$ & $\mathrm{O}_{1.00}$ \\
O6 & $0.80721(9)$ & $0.81648(9)$ & $0.1954(3)$ & $0.0090(2)$ & $\mathrm{O}_{1.00}$ \\
O7 & $0.71637(9)$ & $0.71698(8)$ & $0.8994(3)$ & $0.0105(2)$ & $\mathrm{O}_{1.00}$ \\
O8 & $0.79206(9)$ & $0.73157(9)$ & $0.5360(3)$ & $0.0117(2)$ & $\mathrm{O}_{1.00}$ \\
\hline
\end{tabular}


Table 3. Selected bond lengths ( $\mathrm{A})$ in New York chromium-dravite.

\begin{tabular}{cc}
\hline $\mathbf{N a}(\mathbf{X})-$ & Distance \\
\hline $\mathrm{O} 2(\times 3)$ & $2.533(2)$ \\
$\mathrm{O} 5(\times 3)$ & $2.7065(19)$ \\
$\mathrm{O} 4(\times 3)$ & $2.799(2)$ \\
Mean & 2.680 \\
\hline B- & Distance \\
\hline O8 $(\times 2)$ & $1.3653(18)$ \\
O2 & $1.394(3)$ \\
Mean & 1.375 \\
\hline Al(Z)- & Distance \\
\hline O8 & $1.9330(13)$ \\
O7 & $1.9457(13)$ \\
O8 & $1.9493(14)$ \\
O6 & $1.9580(13)$ \\
O7 & $1.9828(13)$ \\
O3 & $2.0211(9)$ \\
Mean & 1.964 \\
\hline Si- & Distance \\
\hline O7 & $1.5979(12)$ \\
O6 & $1.6089(14)$ \\
O4 & $1.6295(8)$ \\
O5 & $1.6473(9)$ \\
Mean & 1.621 \\
\hline Cr(Y)- & Distance \\
\hline O1 $(\times 2)$ & $1.9659(15)$ \\
O2 $\times 2)$ & $1.9872(13)$ \\
Mean & $2.0256(12)$ \\
\hline & $2.0951(19)$ \\
\hline & 2.014 \\
\hline
\end{tabular}

Table 4. Electron microprobe results of structure crystal.

\begin{tabular}{cccc}
\hline Oxide & wt. \% & Range & Standard \\
\hline $\mathrm{SiO}_{2}$ & 34.72 & $34.40-35.01$ & kyanite \\
$\mathrm{TiO}_{2}$ & 0.97 & $0.90-1.10$ & rutile \\
$\mathrm{Al}_{2} \mathrm{O}_{3}$ & 15.85 & $15.61-16.20$ & kyanite \\
$\mathrm{Cr}_{2} \mathrm{O}_{3}$ & 21.08 & $20.60-21.60$ & chromite \\
$\mathrm{V}_{2} \mathrm{O}_{3}$ & 0.33 & $0.27-0.38$ & $\mathrm{~V}_{2} \mathrm{O}_{5}$ \\
$\mathrm{~B}_{2} \mathrm{O}_{3}$ & 10.18 & $\mathrm{NA}$ & $\mathrm{NA}$ \\
$\mathrm{FeO}$ & 0.15 & $0.09-0.22$ & Syn Fayalite \\
$\mathrm{MgO}$ & 9.87 & $9.70-9.98$ & P140 forsterite \\
$\mathrm{CaO}$ & 1.19 & $1.12-1.26$ & Di ${ }_{2}$ Ti \\
$\mathrm{MnO}$ & 0.06 & $0.04-0.07$ & P140 forsterite \\
$\mathrm{Na}{ }_{2} \mathrm{O}$ & 2.09 & $1.99-2.21$ & jadeite \\
$\mathrm{K}_{2} \mathrm{O}$ & 0.05 & $0.05-0.07$ & OR-1 *** \\
$\mathrm{Li}_{2} \mathrm{O}$ & 0.47 & $\mathrm{NA}$ & NA \\
$\mathrm{F}$ & 0.02 & $0.01-0.04$ & topaz \\
$\mathrm{H}_{2} \mathrm{O}$ & 3.50 & $\mathrm{NA}$ & NA \\
$\mathrm{O}=\mathrm{F}$ & 0.01 & & \\
$\mathrm{Total}^{*}$ & 100.54 & &
\end{tabular}

* Calculated by stoichiometry. Empirical formula (calculated using spreadsheet developed by Julie Selway and Jian Xiong, unpublished data): ${ }^{X}\left(\mathrm{Ca}_{0.22} \mathrm{Na}_{0.69} \mathrm{~K}_{0.01}\right)^{Y},{ }^{Z}\left(\mathrm{Al}_{3.12} \mathrm{Cr}_{2.85} \mathrm{Mg}_{2.51} \mathrm{Li}_{0.31} \mathrm{Ti}_{0.13} \mathrm{~V}_{0.05} \mathrm{Fe}_{0.02} \mathrm{Mn}_{0.01}\right)^{T}\left(\mathrm{Si}_{5.93} \mathrm{Al}_{0.07}\right)$ $\mathrm{B}_{3} \mathrm{O}_{27} \mathrm{OH}_{3.99} \mathrm{~F}_{0.01}$. ${ }^{* *}$ Ti-doped diopside glass, Geophysical Laboratory, Washington, DC, USA. ${ }^{* * *} \mathrm{~K}$-feldspar standard, Geophysical Laboratory, Washington, DC. NA = not analyzed. 


\section{Results and Discussion}

Earlier authors undertook a detailed study on ion substitutions and structural adjustments in Cr-bearing tourmalines [1]. Those authors note that Cr-bearing tourmalines are relatively uncommon, as they will only crystallize in the rare geochemical environments that are rich in B and Cr. In a review of previous studies of $\mathrm{Cr}$-bearing tourmalines as well as the addition of new high precision studies, they asserted that substituent chromium in chromium-dravite occupies the $Y$ site until a concentration threshold is reached, at which point $\mathrm{Cr}$ begins to disorder and occupy both the $Y$ and $\mathrm{Z}$ sites. They propose a threshold $\mathrm{Cr}$ concentration value of $1.03 \pm 0.27 \mathrm{apfu}$ as the point at which disorder commences. We utilize high-quality refinements of the Cr-bearing tourmalines from [1,12] as well as the atomic arrangement of the tourmaline described herein to explore the structural properties and place the New York chromium-dravite in the context of other chromium tourmalines, yielding 10 high-precision structures for comparison.

For those 10 chromium-tourmaline samples, Figure 1 depicts the relationship between the average $\mathrm{Z}-\mathrm{O}$ bond distance $(<\mathrm{Z}-\mathrm{O}>)$ in the $\mathrm{Cr}$-bearing tourmalines and the total amount of substituent $\mathrm{Cr}$ incorporated in the atomic arrangement. As noted there, there is a positive correlation between structural substituent apfu $\mathrm{Cr}$ and $<Z-\mathrm{O}>\left(R^{2}=0.9877\right)$ even when the substituent $\mathrm{Cr}$ is incorporated in the $Y$ site as opposed to the $Z$ site. This relationship was also noted by [1]. Thus, the incorporation of ${ }^{Y} \mathrm{Cr}$ induces changes in the $Z$ polyhedron such that the $Z$ polyhedron size increases. The polyhedron distortions in tourmaline were detailed by [13], who noted that the $Y$ site occupancy greatly influences the properties of the $Z$ site with which it shares edges.

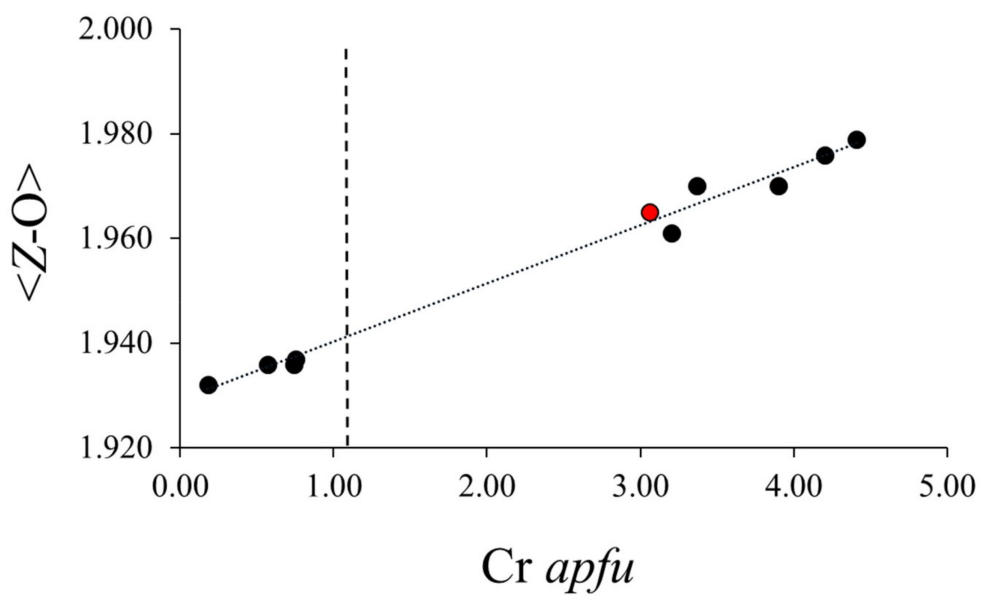

Figure 1. Relationship between $<\mathrm{Z}-\mathrm{O}>$ octahedral bond length $(\AA)$ and total $\mathrm{Cr}$ in 10 chromium-dravite samples cited in text $\left(R^{2}=0.9877\right)$. Vertical line at $\mathrm{Cr}=1.03$ apfu denotes concentration at which $\mathrm{Cr}$ will purportedly begin to enter the Z-site [1]. Red point denotes Balmat tourmaline of this study, remainder of points from $[1,12]$.

Despite the $<Z-\mathrm{O}>$ expansion with the ${ }^{Y} \mathrm{Cr}$ addition, the $\mathrm{Z}$ site in tourmaline is not amenable to $\mathrm{Cr}$ incorporation at low substituent concentrations. The covariance of the Z-site bond valence sum (BVS) for $\mathrm{Cr}^{3+}$ as a function of $\mathrm{Cr}$ apfu is displayed in Figure 2. At low values of substituent $\mathrm{Cr}$, when all the substituent occupies the $Y$-site, the BVS for $\mathrm{Cr}$ in the Z-site is large relative to the formal valence of $\mathrm{Cr}^{3+}$, with the overbonding effectively excluding $\mathrm{Cr}$ from that site.

As noted in the previous discussion of Figure 1, changes induced by $\mathrm{Cr}$ in the $Y$-site change the average bond length in the Z-site. Figure 2 demonstrates that the $\mathrm{Cr}$ substituent not only changes the $\langle\mathrm{Z}-\mathrm{O}\rangle$, but those changes in bond lengths also enhance the BVS for a Cr substituent in $Z\left(R^{2}=0.9915\right)$. Figure 2 also denotes the concentration threshold of $1.03( \pm 0.27 \mathrm{apfu})$, which marks the concentration when $\mathrm{Cr}$ begins to occupy the Z-site. At that concentration value, the BVS for a $\mathrm{Cr}$ substituent in the Z-site is 3.36 valence units (vu). At that value of BVS, $\mathrm{Cr}$ at the Z-site would be overbonded, marking a site of lattice strain, but $\mathrm{Cr}$ is nonetheless accommodated in the Z-site. Disorder of the 
coordinating oxygens may also relieve some overbonding. Thus, the locus of the substitution of the $\mathrm{Cr}$ in octahedral sites in tourmaline is a function of the bonding environment to that substituent, which allows substitution in the $Y$-site at low concentrations and both the $Y$ - and Z-sites at higher concentrations because of the modification of the bonding environment of $\mathrm{Cr}^{3+}$ at that latter site.

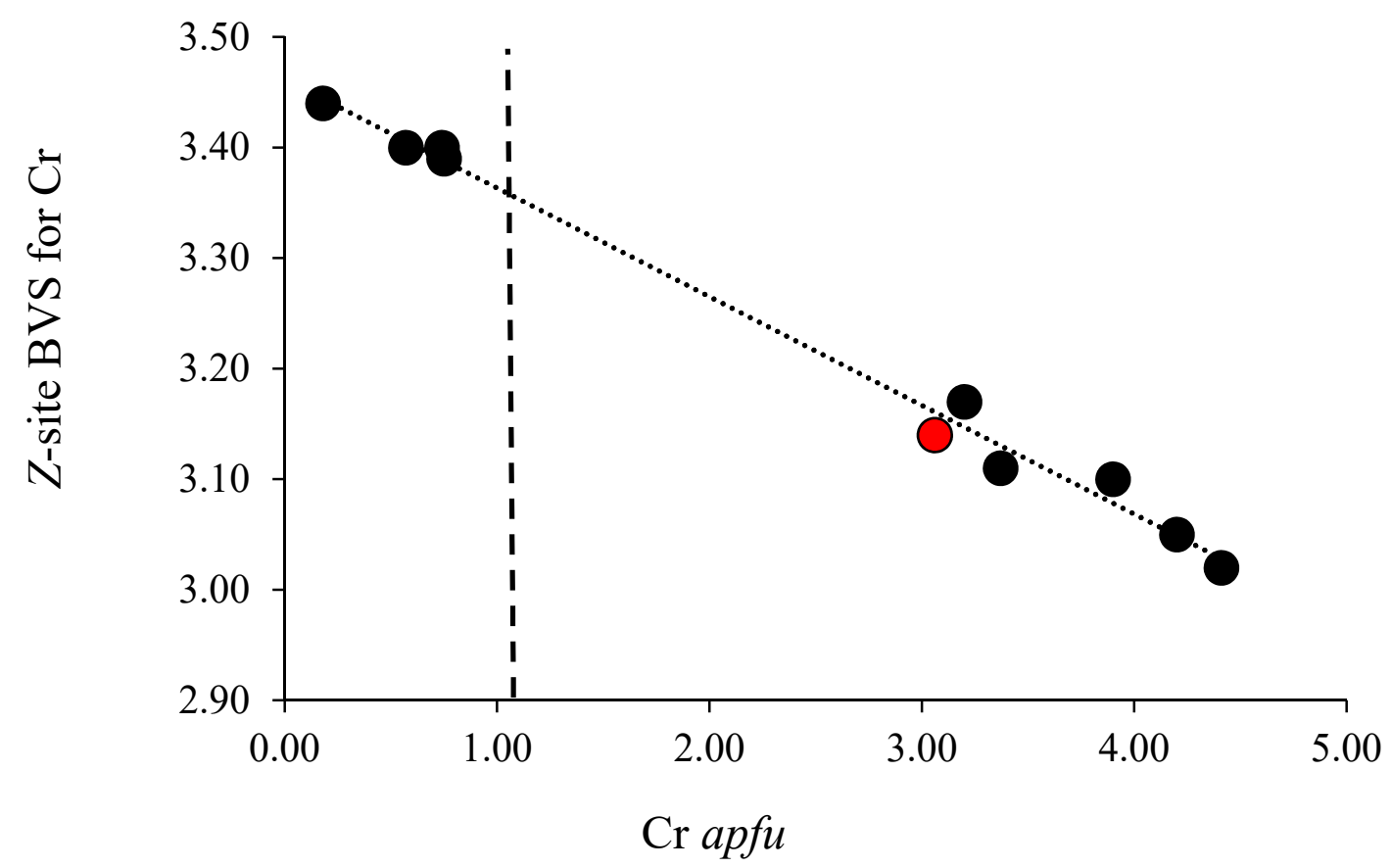

Figure 2. Bond-valence (vu) for $\mathrm{Cr}$ in the tourmaline $\mathrm{Z}$-site for 10 chromium-dravite samples cited in text $\left(R^{2}=0.9915\right)$. Vertical line at $\mathrm{Cr}=1.03$ apfu denotes concentration at which $\mathrm{Cr}$ will purportedly begin to enter the Z-site [1]. Red point denotes Balmat tourmaline of this study, remainder of points from [1,12].

Finally, an optimization of the $Y$ - and Z-site octahedral site occupants was undertaken using the crystal structure refinement results, the chemical analysis of the structure crystal, and program OccQP of [14]. The site refinement sites yielded ${ }^{Y}\left(\mathrm{Cr}^{3+}{ }_{1.68} \mathrm{Mg}_{0.80} \mathrm{Ti}_{0.13} \mathrm{~V}_{0.06} \mathrm{Mn}_{0.02} \mathrm{Fe}_{0.02} \mathrm{Li}_{0.29}\right)$ $\mathrm{Z}_{(}\left(\mathrm{Al}_{3.11} \mathrm{Cr}_{1.18} \mathrm{Mg}_{1.70} \mathrm{Fe}_{0.01}\right)$, demonstrating that $\mathrm{Cr}$ occupies both octahedral sites, confirming recent high-quality structure studies of chromium-dravites with higher amounts of $\mathrm{Cr}[1,6,12]$. By combining the optimization of the octahedral sites with the chemical analysis, the structural formula of ${ }^{X}\left(\mathrm{Ca}_{0.22} \mathrm{Na}_{0.69} \mathrm{~K}_{0.01}\right)^{Y}\left(\mathrm{Cr}^{3+}{ }_{1.68} \mathrm{Mg}_{0.80} \mathrm{Ti}_{0.13} \mathrm{~V}_{0.06} \mathrm{Mn}_{0.02} \mathrm{Fe}_{0.02} \mathrm{Li}_{0.29}\right)^{Z}\left(\mathrm{Al}_{3.11} \mathrm{Cr}_{1.18} \mathrm{Mg}_{1.70} \mathrm{Fe}_{0.01}\right)$ ${ }^{T}\left(\mathrm{Si}_{5.93} \mathrm{Al}_{0.07}\right) \mathrm{B}_{3} \mathrm{O}_{27} \mathrm{OH}_{3.99} \mathrm{~F}_{0.01}$ is attained. In the presentation of the IMA-approved tourmaline nomenclature by [5], the tourmaline with $\mathrm{Cr}$ dominant in $Y$ and $\mathrm{Al}$ dominant in $Z$ with, ideally, $\mathrm{Z}_{(}\left(\mathrm{Al}_{4} \mathrm{Mg}_{2}\right)$, is chromo-alumino-povondraite, which has ideal octahedral occupants of ${ }^{Y}\left(\mathrm{Cr}_{3}\right)^{\mathrm{Z}}\left(\mathrm{Al}_{4} \mathrm{Mg}_{2}\right)$ and $(\mathrm{OH})_{3}$ and $\mathrm{O}$ in the $V$ and $W$ tourmaline sites, respectively. If $\mathrm{OH}$ is dominant in the $W$ site of the present sample (although that occupancy is indeterminate, see previous discussion of the tentative refinement of the $\mathrm{H}$ occupancy associated with the $W$ site), it is a new tourmaline species. However, comparison of the Cr-bearing tourmaline of this study and that of [4], from the same mine, demonstrates a large range in $\mathrm{Cr}$ composition as well as other elements, illustrating large compositional variability in the tourmalines from the Balmat \#1 mine. An extensive study of the Cr-rich tourmalines to define new species and investigate the compositional variability of the tourmalines of the mine is warranted.

Supplementary Materials: The following are available online at http://www.mdpi.com/2075-163X/9/7/398/s1, CIF File with imbedded structure factors and are available online at https:/www.uvm.edu/sites/default/files/ Department-of-Geology/MLCRTUR_0mREVISEDNa.cif_.txt.

Author Contributions: Conceptualization, J.M.H., M.V.L.; methodology, J.M.H., M.V.L., validation, S.G.D., D.D.P., A.M.E., K.P.M., M.T.M., M.B.R., D.M.S.J., Z.S., M.I.V., X.Z.; formal analysis, M.V.L., J.M.H, A.M.E, M.B.R., S.G.D., D.M.S.J.; investigation, S.G.D., D.D.P., A.M.E., K.P.M., M.T.M., M.B.R., D.M.S.J., Z.S., M.I.V., X.Z., J.M.H., M.V.L.; 
resources, M.V.L., J.M.H.; data curation, M.V.L., J.M.H.; writing—original draft preparation, S.G.D., D.D.P., A.M.E., K.P.M., M.T.M., M.B.R., D.M.S.J., Z.S., M.I.V., X.Z., J.M.H.; writing-review and editing, S.G.D., D.D.P., A.M.E., K.P.M., M.T.M., M.B.R., D.M.S.J., Z.S., M.I.V., X.Z., J.M.H., M.V.L.; visualization, S.G.D., D.D.P., A.M.E., K.P.M., M.T.M., M.B.R., D.M.S.J., Z.S., X.Z., J.M.H.; supervision, J.M.H.; project administration, M.V.L., J.M.H.; funding acquisition, M.V.L., J.M.H.

Funding: This study was funded, in part, by grant U.S. NSF-MRI 1039436 from the National Science Foundation to JMH, and by the New York State Museum (MVL).

Acknowledgments: The manuscript was improved by reviews by anonymous reviewers, for which we are grateful. The student authors of this work are part of an advanced course in Crystal Chemistry at the University of Vermont, and the College of Arts and Sciences and Department of Geology are thanked for support of this work.

Conflicts of Interest: The authors declare no conflict of interest.

\section{References}

1. Vereschagin, O.S.; Rozhdestvenksa, I.V.; Frank-Kamenetskaya, O.V.; Zolotarev, A.A. Ion substitutions and structural adjustment in Cr-bearing tourmalines. Eur. J. Mineral. 2014, 26, 309-321. [CrossRef]

2. Bosi, F.; Reznitskii, L.; Halenius, U.; Skoby, H. Crystal chemistry of Al-V-Cr oxy-tourmalines from Sludyanka complex, Lake Baikal, Russia. Eur. J. Mineral. 2017, 29, 457-472. [CrossRef]

3. Vereshchagin, O.S.; Frank-Kamenetskaya, O.V.; Rozhdestvenskaya, I.V.; Zolotarev, A.A. Incorporation of 3d elements in tourmalines: structural adjustments and stability. Eur. J. Mineral. 2018, 30, 917-928. [CrossRef]

4. Lupulescu, M.V.; Rowe, R. Al-rich chromium-dravite from the \#1 Mine, Balmat, St. Lawrence County, New York. Can. Mineral. 2011, 49, 1189-1198.

5. Henry, D.J.; Novák, M.; Hawthorne, F.C.; Ertl, A.; Dutrow, B.L.; Uher, P.; Pezzotta, F. Nomenclature of the tourmaline-supergroup minerals. Am. Mineral. 2011, 96, 895-913. [CrossRef]

6. Bosi, F.; Reznitskii, L.; Skogby, H. Oxy-chromium-dravite, $\mathrm{NaCr}_{3}\left(\mathrm{Cr}_{4} \mathrm{Mg}_{2}\right)\left(\mathrm{Si}_{6} \mathrm{O}_{18}\right)\left(\mathrm{BO}_{3}\right)_{3}(\mathrm{OH})_{3} \mathrm{O}$, a new mineral species of the tourmaline supergroup. Am. Mineral. 2014, 97, 2023-2030. [CrossRef]

7. Brown, C.E. Mineralization, Mining, and Mineral Resources in the Beaver Creek Area of the Grenville Lowlands in St. Lawrence County, New York; USGS Prof. Paper 1279; USGS Publications Warehouse: Reston, VA, USA, 1983. [CrossRef]

8. Brown, C.E.; Ayuso, R.A. Significance of Tourmaline-Rich Rocks in the Grenville Complex of St. Lawrence County, New York; USGS Bulletin 1626-C; U.S. Government Printing Office: Washington, DC, USA, 1984; pp. 1-33.

9. Slack, J.F.; Herriman, N.; Barnes, R.G.; Plimer, I.R. Stratiform tourmalinites in metamorphic terranes and their geologic significance. Geology 1984, 12, 713-716. [CrossRef]

10. Chiarenzelli, J.; Lupulescu, M.; Thren, E.; Cousens, B. Tectonic implications of the discovery of Shawinigan ophiolite (Pyrites Complex) in the Adirondack Lowlands. Geosphere 2011, 7, 333-356. [CrossRef]

11. Sheldrick, G.M. Crystal Structure refinement with SHELX. Acta Cryst. 2015, C71, 3-8.

12. Bosi, F.; Lucchesi, S.; Reanitsku, L. Crystal chemistry of the dravite-chromdravite series. Eur. J. Mineral. 2004, 16, 345-352. [CrossRef]

13. Ertl, A.; Hughes, J.M.; Pertlik, F.; Foit, F.F., Jr.; Wright, S.E.; Brandstátter, F.; Marler, B. Polyhedron distortions in tourmaline. Can. Mineral. 2002, 40, 153-162. [CrossRef]

14. Wright, S.E.; Foley, J.A.; Hughes, J.M. Optimization of site occupancies in minerals using quadratic programming. Am. Mineral. 2000, 85, 524-531. [CrossRef]

(C) 2019 by the authors. Licensee MDPI, Basel, Switzerland. This article is an open access article distributed under the terms and conditions of the Creative Commons Attribution (CC BY) license (http://creativecommons.org/licenses/by/4.0/). 